\title{
FINANCIAL PERFORMANCE AND FIRM VALUE: DOES INTERNET FINANCIAL REPORTING MODERATE THE RELATIONSHIP IN INDONESIAN MANUFACTURING COMPANIES?
}

\author{
Linda Agustina ${ }^{1 \star}$, Dhini Suryandari ${ }^{2}$ \\ ${ }^{1}$ Ms., Universitas Negeri Semarang, INDONESIA, lindaagustina@mail.unnes.ac.id \\ ${ }^{2}$ Ms.,Universitas Negeri Semarang, INDONESIA, dhini.surya@gmail.com \\ ${ }^{*}$ Corresponding author
}

\begin{abstract}
Good financial performance of the company is the primary consideration by investors in making investment decisions. Improved financial performance is expected to increase the firm value, so that the higher financial performance, the higher the firm value. The firm value for investors and creditors are very important and they are increasingly selective in investing or providing credit to the company. Therefore accurate information about the condition of the company is needed, one of them by Internet Financial Reporting (IFR). The disclosure of financial information in the IFR will give a good or bad signal to investors, so that investors are interested and believe to invest their fortune to the company. The purpose of this study was to analyze the effect of the financial performance on firm value moderated by Internet Financial Reporting (IFR.). The populations were the entire manufacturing companies listed in Indonesia Stock Exchange in 2014-2015. The sampling technique used purposive sampling and selected 92 companies. The data were analyzed using descriptive statistical analysis and Structural Equation Modeling using Partial Least Squares (PLS-SEM). The results showed that IFR capable of strengthening the effect of financial performance on firm value. When the company use IFR to transfer positive signal to the investors, and they responded positively by invest into the company, so the effect of financial performance on firm value becomes stronger. The results of this study indicated that IFR in Indonesia has able to provide the benefits in transferring the company's positive signal to investors. Further research can use different types of company due to obtain a more real description
\end{abstract}

Keywords: financial performance, internet financial reporting, firm value.

\section{INTRODUCTION}

One of the main considerations of investor in making a company investment decision is a good financial performance (Ganto et al., 2008). For investors, financial performance measurement becomes a fundamental aspect to invest because it can describe the real condition of the company. Financial performance can be increased on an ongoing basis when companies implement the appropriate business strategy. Improved financial performance is expected to increase the value of the company. Every company 
will always maintain its good firm value even increased. However, the Global Financial Crisis in 2008 led to many companies in Indonesia impaired, even eight companies delisted from the Indonesia Stock Exchange.

Firm value is affected by several variables; one of them is financial performance. Measurement the level of management success in managing company's financial resources can be seen from the financial performance. Andri and Hanung (2007) states that the higher the financial performance that proxied by financial ratios then the higher firm value. Mahendra (2011) reveals the profitability able to affect the firm value significantly, because of the high profitability means there is guarantee of high profit sharing. It is desired by investors. Putri (2013) states the investors need information to notice the prospects of the company and associated with costs to be incurred by investors in investing. Investors prefer companies that more disclose information about the condition of the company. With the more information that disclosed the company, investors assume that the risk of the company is low. One of information sources for external parties, both investors and creditors in assessing the financial performance of the company is through Internet Financial Reporting (IFR).

Internet Financial Reporting (IFR) is a method used by companies to report their financial information via the Internet, on the company's official website. Fitriana (2009) describes that IFR enables investors to access corporate information. As for the company, IFR provides an easy to disseminate financial information with low cost and fast, because it can reduce the cost to print and send corporate information to investors. Based on signalling theory when the company showed good performance, management has a strong encouragement to disseminate information of the company, especially financial information in order to increase investor confidence (Oyelere et al., 2003). The disclosure of financial information, one of them through the IFR on the company's website. Since 2012 the Financial Services Authority in Indonesia has required listed companies or public companies to have a website, which contains the annual report.

The disclosure of financial information through the IFR will give a good or bad signal to investors so that investors are interested and believe to invest their wealth to the company. Many investors who invest will increase the firm value. Companies that have a good financial performance will distribute it widely, one of them through the IFR to be known by outsiders. Instead companies that have financial performance less than optimal will attempt to hide that information in various ways, so that outsiders had little influence on the performance. Based on these descriptions allegedly IFR able to moderate the relationship between the value of the company's financial performance. The purpose of this study was to analyze the effect of financial performance on firm value moderated by Internet Financial Reporting.

\section{LITERATURE REVIEW}

The basic theories in this study are agency theory and signal theory. Agency theory developed by Jensen and Meckling (1967) states a contract between one or more persons (the principal) that involves another person (Agent) to perform some service on behalf of the principal and authorized agent to make the best decisions for the principal. Kusumawardani (2011) suggested that the main principle of agency theory is the existence of the relationship of cooperation contract between the authorizing, ie shareholders (principals) with those who receive the authority (agent) ie the manager of the company. When the shareholders appoint the manager to manage and as a corporate decision-making, then the agency relationship appear. Agustina (2008) stated that in the contract between the manager and the shareholders, then the agent as the management of company wealth will prepare its financial statements as a means of agent accountability to the principal. As a form of accountability, the agent will try to fulfill all of the principal wishes, in this case is the disclosure of financial information more widely, one of them through IFR on the company's website.

Signaling theory defines how management as an agent convey signals success or failure to the owner as a principal. Signaling theory indicate asymmetry of information between the company's management with the parties who need information company. This happens because managers learn more the information about the company and upcoming prospect than outsiders (investors, creditors). One way to reduce the asymmetry of information is to give a signal to outside parties, one of them a reliable financial information and it will reduce the uncertainty about the upcoming company prospects (Wolk et al., 2000). Signalling theory emphasizes the importance of information released by the company to investment decisions to parties outside the company. The practice of financial reporting through the internet on the company website is a medium for conveying information in order to reduce information asymmetry and agency costs (Prastiwi and Puspitaningrum, 2012).

Signal theory explains that the management has a strong encouragement to show a good performance of the company to spread the information to outside parties. It can be implemented through IFR. Companies with poor performance will avoid the use of techniques such as Internet Financial Reporting because they are trying to hide bad news. In contrast to companies that have high financial performance, they use IFR to 
help companies disseminate good news. Financial performance can be seen of the company profitability. Profit generated by the company is a result that's expected by managers and investors of the company (Tedjo, 2012). Companies that have a high level of profitability tend to more disclose the information about profitability because they want to show to the public and stakeholders that the company has a high level of profitability compared with other companies in the same industry, so that the stakeholders can assess the competitive position of the company (Almilia 2008 ).

Rahayu (2010) states that the higher profitability of a company can be a positive signal for investors in making investments to obtain a certain return. One of the main reasons the company operates is to generate profits for shareholders. The measure of this success is the greater Return on Equity (ROE) that would reflect a high ability for shareholders (Wardoyo and Veronica 2013). Companies that have high profitability will disclose financial information through the IFR as a good news to investors. The existence of positive signals are expected can attract the investors to infuse their capital to the company, so that the firm value can be increased. Companies with lower profitability tend to hide bad news so that investors are not very influential on the negative signals. The hypothesis in this research is Internet Financial Reporting affords to moderate the effect of financial performance on firm value.

\section{METHODOLOGY}

The population in this study were all manufacturing companies listed in Indonesia Stock Exchange in $2014-$ 2015 as many as 124 companies. The samples obtained using purposive sampling with the established criteria were (1) listed in Indonesia Stock Exchange in 2014-2015 and in the Rupiah currency (IDR); (2) have a corporate website can be accessed or not being in a period of improvement during the research performed; (3) have the financial information related to the research variables. The sample selection procedure described in Table 1 below:

\section{Table 1. Sample Selection Procedures}

\begin{tabular}{|c|l|c|}
\hline No. & \multicolumn{1}{|c|}{ Information } & Amount \\
\hline 1 & Manufacturing companies listed in Indonesia Stock Exchange in 2014-2015 & 124 \\
\hline 2 & Using currencies other than Rupiah (IDR) & $(22)$ \\
\hline 3 & Not having the company's website that can be accessed & $(6)$ \\
\hline 4 & Presented financial statements are incomplete & $(4)$ \\
\hline & The number of companies that can be used as a sample & 92 \\
\hline
\end{tabular}

Table 1 presented the manufacturing companies that listed on Indonesia Stock Exchange which can be sampled only 92 companies.

This research examined three variables. There were firm value as the dependent variable, IFR as moderating variables and financial performance as independent variables. The firm value was measured by the Price to Book Value (PBV) in a way the market price per share divided by the book value per share. IFR was proxied by Internet Financial Reporting Index as many as 82 items, measured by the number of scores disclosed divided by the total score. Financial performance was proxied by profitability using Return on Equity (ROE). The formula of ROE was calculated as net income divided by total assets.

Collecting data in this research used documentation techniques. The data collected were secondary data in the form of financial statements and annual report on the company's website. The search of company website address has done by using a search engine Google and yahoo. Analysis of the data used descriptive statistical analysis and hypothesis testing used analysis Partial Least Square-Structural Equation Modeling (PLS-SEM).

\section{RESULTS}

The test results of descriptive statistics in Table 2 below:

Table 2. Descriptive Statistics Analysis

\begin{tabular}{|c|r|r|r|r|}
\hline Variables & \multicolumn{1}{|c|}{ Minimum } & \multicolumn{1}{c|}{ Maximum } & \multicolumn{1}{c|}{ Mean } & \multicolumn{1}{c|}{ Std. deviation } \\
\hline PBV & -4.6279 & 4.0687 &, 114060 & 1.3237579 \\
\hline ROE & -1.8326 & 5.0945 & 2.334273 & 1.2488320 \\
\hline IFR & 39.0244 & 82.9268 & 60.843054 & 9.6946883 \\
\hline
\end{tabular}

Table 2 illustrates the average value of the variables is greater than the standard deviation except PBV. PBV 
or the value of manufacturing companies in the research's sample was viewed by investors as varied characterized by the value generated was negative or positive, but PBV of manufacturing companies in this research in less than optimal conditions for the average value below the standard deviation. ROE has a value between -1.83 and 5.0945 which means that manufacturing companies in this research have the ability to generate profits are different, but when viewed from the average value, in general group of manufacturing companies were able to generate profits in the business. IFR positive value indicated that the group of manufacturing companies in this research had implemented Internet Financial Reporting.

The hypothesis in this study was tested using PLS-SEM analysis with Warp PLS. The results of structural model evaluation showed the overall model fit. The results of hypothesis testing in Table 3 below:

Table 3 Hypothesis Testing Results

\begin{tabular}{|l|c|c|c|c|}
\hline Hypothesis & Coefficient & P-value & $\alpha$ & Conclusion \\
\hline $\begin{array}{l}\text { IFR affords to moderate the effect of ROE } \\
\text { on PBV }\end{array}$ & 0,270 & 0,006 & 0.05 & $\mathrm{H}_{1}$ accepted \\
\hline
\end{tabular}

Table 3 showed that IFR affords to moderate the effect of ROE on PBV. It means that the Internet Financial Reporting can increase the effect of financial performance of firm value. Signaling theory has explained that the company will do the same with similar companies in the disclosure of financial information. If a company makes a disclosure through the company website, then similar companies will do the same in order not considered to conceal a bad thing (Craven and Marston, 1999). The manufacturing companies that have implemented IFR based on data as much as 118 companies from total of 124 companies. It's because of ROE value of manufacturing companies in this research were in good condition to make a profit. It can be seen in Table 2 that the average value of ROE over of the standard deviation. It can be explained by signaling theory that good information about the company will be disclosed as soon as possible by the management. One of the disclosure media of company information was through the company website by Internet Financial Reporting (IFR). The results of this research also support the agency theory that the manager as the agent will disclose corporate information widely to reduce information asymmetry. It is as a form of accountability the agent as a party who is authorized by the principal.

\section{CONCLUSIONS}

Internet Financial Reporting (IFR) that practiced by the company was able to moderate the effect of financial performance on firm value. Financial performance as measured by profitability ratios proved to be able to influence the firm value and IFR capable of making these influence become stronger. It is proved that Internet Financial Reporting has been done by manufacturing companies in Indonesia Stock Exchange is able to provide the benefits in transferring the company's positive signal to investors.

Companies in Indonesia are expected to perform IFR to meet criteria that assessed useful by stakeholders to financial analysis because the average of Internet Financial Reporting index was not up to one hundred percent. Further research can be conducted on a group of companies besides manufacturing in order to obtain a more real description, with consideration of the differences in the characteristics of the company and the application of technology to business processes are also different.

\section{REFERENCE LIST}

Agustina, Linda. (2008). Pengaruh Karakteristik Perusahaan terhadap Luas Pengungkapan Informasi Keuangan pada Website Perusahaan. Jurnal Dinamika Akuntansi Vol 1, N0. 2, September 2009, pp. 133-144.

Almilia, L.S. (2008). Faktor-Faktor Yang Mempengaruhi Pengungkapan Sukarela Internet Financial And Sustainability Reporting. Jurnal Akuntansi dan Auditing Indonesia, Vol. 12, No. 2, Desember 2008.

Andri, Rachmawati dan Hanung Triatmoko. (2007). Analisis faktor - faktor yang mempengaruhi kualitas Laba dan Nilai Perusahaan, SNA X Makasar, Hal 1-26.

Craven, B.M. and C.L. Marston.(1999). Financial Reporting on the Internet by Leading UK Companies. The European Accounting Review. Vol. 8. Iss. 2. pp:.321 - 333.

Fitriana, Meinar Rakhma. (2009). Analisis Pengaruh Kompetisi dan Karaktristik perusahaan terhadap Luas 
Pengungkapan Informasi Keuangan dalam website Perusahaan. Skripsi Tidak Dipublikasikan , Program Sarjana Fakultas Ekonomi Universitas Diponegoro.

Ganto. (2008). Pengaruh Kinerja Keuangan Perusahaan Terhadap Return Saham di Bursa Efek Indonesia. Media Riset Akuntansi, Auditing, dan Informasi. 8(1): 85-96.

Jensen, Michael C. and Meckling, William H. (1976). Theory of The Firm: Managerial Behaviour, Agency Cost and Ownership Structure. Journal of Fiancial Economics 3 (1976) 305-360.

Kusumawardani, Arum. (2011). Analisis Faktor-Faktor yang Mempengaruhi Pelaporan Keuangan Melalui Internet (Internet Financial Reporting) dalam Website Perusahaan. Skripsi. Semarang: Universitas Diponegoro.

Mahendra, Alfredo.(2011). Pengaruh Kinerja Keuangan terhadap Nilai Perusahaan (kebijakan Dividen Sebagai Variabel Moderating) Pada Perusahaan Manufaktur Di BEl. Universitas Udayana.

Oyelere, P. B., F. Laswad, dan R. Fisher. (2003). Corporate Financ ial Repor tin g: Firms Characteristic and the Use of Internet as a Medium of Communication. Commerce Divisio n Disc usion Paper. 2003

Puspitaningrum, Ayu dan Prastiwi, Arum. (2012). Pengaruh Karakteristik Perusahaan terhadap Pengungkapan Internet Financial and Sustainability Reporting (IFSR)(Stud pada Perusahaan yang Terdaftar di Bursa Efek Indonesia). Jurnal IImiah Mahasiswa FEB 1.2 (2012).

Putri, Deasy R. (2013). Analisis Faktor-faktor yang Mempengaruhi Indeks Pelaporan Keuangan Melalui Internet. Jurnal Reviu Akuntansi dan Keuangan. ISSN: 2088-0685 Vol. 3 No.1, April 2013 pp 383-390.

Rahayu, Sri. (2010). Pengaruh Kinerja Keuangan Terhadap Nilai Perusahaan Dengan Pengungkapan Corporate Social Respocibility dan Good Corporate Governance Sebagai Variabel Pemoderasi. Universitas Diponegoro, Semarang.

Tedjo, Pauline P. (2012). Peranan Leverage Keuangan, Ukuran, Profitabilitas, dan Tipe Kepemilikan Perusahaan terhadap Pengungkapan Sukarela Perusahaan dalam Media Internet. Berkah IImiah Mahasiswa Akuntansi

Wardoyo dan Theodora Martina Veronica.(2013). Pengaruh Kinerja Keuangan, Good Corporate Governance dan Corporate Social Responsibility terhadap Nilai Perusahaan. Jurnal Dinamika Manajemen Vol. 4, No. 2, 2013, pp: 132-149

Wolk et al. (2000). Accounting Theory: A Conceptual Institutional Aproach Fifth Edition. South Western College Publishing. 